\title{
OPEN GOVERNMENT: A TOOL FOR DEMOCRACY?
}

\section{Emiliana De Blasio :: Michele Sorice}

IZVORNI ZNANSTVENI RAD / DOI: 10.20901/ms.7.14.3 / PRIMLJENO: 18.03.2016.

\begin{abstract}
The growing disconnection between citizens and decision-makers is pushing politics towards a re-shaping of institutional design. New spaces of political participation are sustained and even reinforced by communication, especially by digital communication. Governments and public administrations can find and use different models to facilitate citizens' participation; e-government, open government and a specific design of digital democracy. In this respect, open government can constitute a way to re-connect citizens and political institutions, but at the same time, it can also be an "appealing" tool to institutionalize bottom-up participation and so anesthetizing it. The aim of this article is to present the first findings of an international research project about open government and participatory platforms in four European countries (France, Italy, Spain, the UK). The study tries to understand if participatory platforms can improve the quality of democracy, and if open government can contribute to democratizing democracy.
\end{abstract}

KEY WORDS

OPEN GOVERNMENT, PARTICIPATION, COMMUNICATION, DEMOCRACY, DEMOCRATIC INNOVATIONS

Authors note

Emiliana De Blasio :: LUISS University, Department of Political Sciences, Rome, Italy and SciencesPo, Paris, France :: edeblasio@luiss.it

Michele Sorice :: LUISS University, Department of Political Sciences, Rome, Italy and University of Stirling, Communication Media and Culture, Scotland, UK :: michele.sorice@stir.ac.uk 


\section{DISSATISFIED DEMOCRACY}

Contemporary democracies have developed into party democracies. Political parties, "the key institutions of democratic governments," in the words of Richard S. Katz, have held "a number of key functions in governing process, including mobilization and channelling of support, formulation of alternatives, recruitment and replacement of leadership, and, when in power, implementation of policy and control over its administration" (1987: 37).

The end of the twentieth century brought to light a number of problems and challenges for party governments, to the extent that Giovanni Sartori talked about "the era of confusion of Democracy" (1987: 3). Max Kaase and Kenneth Newton speak explicitly of the "crisis of democracy", with "reference to the disenchantment of citizens with political parties, the emergence of anti-party attitudes, and the growing incidence of more general dissatisfaction and anti-establishment attitudes" (1995: 150, also cited in Morlino, 2011: 210).

In such disaffected democracy (Pharr and Putnam, 2000) contemporary parties failed in performing their core representational and governmental functions linked to the transmission of political demand (Easton, 1965). The gradual disaffection of citizens in political life and the consequent decrease in the degree of social participation are accompanied by new types of relationships between parties and citizens. Peter Mair (2000) introduces the expression partyless democracy to stress the progressive erosion of ties (or cleavages, in the words of Lipset and Rokkan, 1967) of parties' legitimation and the rise of the "plebiscitary model of leadership and representation" (Fishkin, 1991: 46).

This trend led to the affirmation of political figures defined by Sergio Fabbrini as democratic princes (1999), whose "personalization of power" meant the shift of loyalty from parties to candidates and the consequent strengthening of the public role of the leader. The weight of individual actors in the political process increased over time (Rahat and Shaefer, 2007), with personalized structure of power. A refurbished plebiscitary leadership, which finds its roots in the processes of mediatisation of political life, with political systems "influenced by and adjusted to the demands of the mass media in their coverage of politics" (Asp, 1986: 359), whose main effect is the decline of "the capacity of political actors to act according to the interests and desires of citizens" (Dalton, 2000: 25).

The problem that strongly emerges here is that of democratic quality, as theorized by Larry Jay Diamond and Leonardo Morlino (2005), especially in regards to the fundamentals of political participation. Leonardo Morlino identifies a paradoxical consequence in this context of

declining parties: on the one hand, there is still an individual need for the external control of reality, as well as a desire for a 'secondary control', but on the other hand the parties no longer offer a credible response in terms of their organization, identification, and ideologies (2011: 133).

While party membership is declining and citizens become more and more disenchanted with traditional forms of participation, democratic innovations give 
citizens the opportunity to influence political decision-making in an institutionalized setting of deliberative or direct democratic procedures. Participatory practices such as deliberative polls, participatory budgeting, the different types of mini-publics and so on, have the potential to respond to the deficits of the representative democratic system and thus contribute to its legitimacy. In fact, one of the implicit assumptions of democratic innovation is that a more active and massive citizens' participation is not only desirable, but that it constitutes the essential dimension so that a democracy can respond effectively to what we commonly call democracy or, in a more precise way, it can be consistent with the normative definitions of democracy. At the same time, however, the idea of democratic innovation tends to reject (or to deviate from) too normative definitions of democracy, since it stems from the practices of participation and not by a predetermined model of "desirable" democracy. lan Shapiro (2003), in this regard, has effectively highlighted the deep gap between the normative theories (seeking to justify and legitimize democracy as a system of government) and explanatory theories (who seek to describe and understand the dynamics of the democratic system). Just out of the impasse represented by the gap between normative theories and explanatory ones, Morlino (2011) proposed to adopt a different analytical perspective, introducing the concept of quality of democracy. For the purposes of this paper when we speak about democratic innovation and collaborative governance we are referring to four main variables: a) specific procedures; b) means of collaborative governance; $c$ ) the adoption of participatory platforms (the Internet) and, finally, d) a more or less defined direct democracy. ${ }^{1}$ These variables are also used to explain the concept of "open government," which is theoretically different from democratic innovation, but frequently overlaps with the latter concept.

The expression open government has relied deeply on an extensive debate about models of governance and decision-making for the last twenty five years (Crouch, 2011). A traditional definition of open government is based on transparency, access to information and accountability, but in recent times the concept has begun to be stretched further (Clarke and Francoli, 2014). As a point of reference, we can highlight two official documents defining it: in November 2009 European governments agreed on the Malmö Ministerial Declaration on e-Government, affirming that public administrations must be "open, flexible and collaborative in their relations with citizens and businesses." In December 2009, US President, Barack Obama, launched the Open Government Initiative, whose "principles of transparency, participation, and collaboration form the cornerstone of an open government." In particular, open government is thought to be challenging previous models of the public sector's agency and structure, such as the bureaucratic State and the New Public Management (Hood and Peters, 2004; Pollitt and Bouckaert, 2004), by defining new forms of relationship among government, citizens and digital technologies².

\footnotetext{
${ }^{1}$ The term collaborative governance refers to forms of cooperative management of public policies, through participatory tools: the best known example (and also most studied) of cooperative governance is the so-called "participatory budget".

${ }^{2}$ We have also to underline that the strong persistence of the New Public Management (NPM) paradigm has partially contributed to the semantic shifting from "government" to "governance," but at the same time it hindered the establishment of a collaborative governance approach, at least in some countries like the UK (and partially in Italy); on the opposite side, in countries like France, with a strong tradition of democratic participation and organized movements, collaborative governance was more easily established, despite (or perhaps because of) the presence of a strong central state. In other words, the abandonment of the NPM paradigm, partly happened in the UK since the first Blair government, facilitated experiences of deliberative democracy, but not necessarily in the frame of collaborative governance; on the opposite side, in France, collaborative governance has been established over traditions of participation and some formal institutions, such as that of "public debate" (débat public).
} 


\section{OPEN GOVERNMENT: BETWEEN EFFICIENCY AND PARTICIPATION}

One of the rhetorical arguments that accompanied the advance of neoliberalism ${ }^{3}$ - or, more correctly, its resistance to the crisis it had itself provoked (Crouch, 2011) - found its strong points in two keywords: 1) quantity, and 2) efficiency.

The concept of quantity is closely linked to that of "accumulation," but unlike the latter, it does not only involve the economic sphere. In does in fact relate to the need for a wide range of services, or rather an ample quantity of services, although this is actually just in theory. Consider, for example, the provision of complex services with high business costs, such as the exploitation of groundwater or energy supplies: entering the market involves facing strong competition, although this is not necessarily true because - precisely because of the costs and the know-how required - only a very few large companies are in a position to compete. Moreover, winning a contract means acquiring the right to a long-term concession (usually 20-25 years), which then becomes a de facto monopoly. In practice, a large quantity of competitors does not lead to greater consumer choice, but simply to increased opportunities for just a few corporations and to the re-establishment of a monopoly (a private rather than a state monopoly).

The concept of efficiency, however, is often defined through its temporal dimension; according to this definition, an efficient state would be one in which there is a very short reaction time between making policy proposals and carrying them out. In short, a state with rapid, effective decision-making procedures that are often legitimized by the spectacle of rules of the so-called "audience democracies" (Manin, 1995). An efficient state therefore requires a strong executive at the centre and has no need for the red tape of parliamentary procedures: this leads to the idea that parliaments should reduce their competencies (or perhaps even disappear or be replaced by more "lightweight" institutions).

In actual fact, these two concepts, though necessary for the development and affirmation of neoliberal ideology, are a long way from the idea of democracy as a political space capable of effectively meeting the needs, requirements and projects of its citizens. Democracy needs neither the imperfect competition that generates monopolies nor frantically reduced decision-making times; what it really needs is to see a growth in its own qualities, or rather in its responsiveness. In some theoretical perspectives - such as the New Public Management Approach - open government is used as a tool to replace the need for government and political debate with the rhetorical storytelling of "governance" (which is very often interpreted as a mere "collection" of public policies). This rhetorical use of the word "governance" is supported by the ideological use of the concept of efficiency.

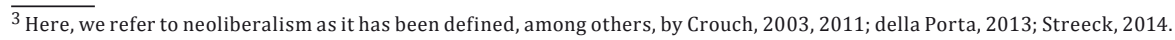




\section{OPEN GOVERNMENT AND PARTICIPATION}

Since its earliest appearances in official discourses, policy programs and academic articles, open government has been defined by comparing it with previous models of administrative structure and agency. In particular, Beth Simone Noveck (2010) identified the core driver of change in openness vs. closeness: she juxtaposes open government to the closed, highly hierarchical and monolithic model of decision making that has served as a distinctive feature of bureaucratic systems since the description given by Max Weber (Weber, 2002). Having in mind the example of Barack Obama's 2008 electoral campaign, Noveck claims that with the advent of collaborative practices through the Internet, theories of direct and deliberative democracy regained their strength, sustained by a network approach to the study of society and organizations (Castells, 1996). Stephen Osborne (2010) takes this argument further, observing the emergence of a "networked governance" or "new public governance" rooted in government's ability to form communities and networks with private actors and citizens.

In effect, the bureaucratic state has already been challenged by the latter: the New Public Management doctrine spread across the world since the late 1970s and 1980s, especially in (but not limited to) the United States, the United Kingdom and several other countries, ${ }^{4}$ while the doctrine has been implemented less in most European countries (Osborne, 2010; Mulgan, 2014). It found a fertile ground in the context of administrative change driven by four "megatrends:" (1) the willingness to decrease public spending and staffing; (2) the shift towards privatization, quasi-privatization and subsidiarity between public and private actors; (3) the increasing use of automation and ICT; and (4) the process of the internalization of policies and of policy coordination at a supra-national level.

Since the mid 1990s and with more insistence through the 2000s, scholars increasingly started to talk about the New Public Management (NPM) being overcome. For example, Robert Denhardt and Janet Vinzant Denhardt (2000) wrote about a "New Public Service" rooted in theories of participatory and deliberative democracy; Archon Fung and Eric Olin Wright (2001) described cases of "empowered participatory governance;" Christopher Hood and Guy Peters (2004) claimed for the "middle aging" of NPM becoming paradoxical and generating unintended consequences; Patrick Dunleavy et al., (2005) asserted the death of NPM and observed the emergence of a "Digital Era Governance;" Stephen Osborne (2010) proposed the "networked governance" or "new public governance," as already cited. As this incomplete list suggests, a part of the scientific community has detected a crisis in the hegemony of NPM, and as a result become in favour of other models. ${ }^{5}$

\footnotetext{
$\overline{4}$ The most important reason why New Public Management settled especially in United States and United Kingdom is that in such countries the neoliberal approach in economics has always been particularly strong. As Colin Crouch explained, NPM is part of a neoliberal approach to the economy and to the organization of the relationship between the State and the citizenry that stresses some of the propositions of classical liberalism, in particular the limitation of public intervention in the economy, pushing it towards more radical positions, such as the privatization of services and the transformation of all social relationships, including the concept of citizenship, by adopting an economic model (Crouch, 2011).

5 Notwithstanding, there are also some relevant exceptions: for example, Helen Margetts and Patrick Dunleavy (2013) account for the persistence of NPM helped by the austerity policies. Colin Crouch (2011) and John Michael Roberts (2014) have also expressed similar thesis. We have also to cite the insurgence of the Public Value Approach as an alternative to NPM.
} 
In particular, as Lisa Blomgren Bingham (2010) claimed, open government programs (especially the White House "open government initiative") rely heavily upon the collaborative governance model, insofar as they aim to involve actors like citizens, private companies and non-profit organizations in the policy-making process, through both inperson and online methods. In defining the concept of collaborative governance, Chris Ansell and Alison Gash (2007) stress six points:

$>$ Public agencies and institutions are the primary promoter of collaborative practices, in the sense that collaborative governance remains a way of exercising public authority; $>$ Multiple non-state stakeholders are involved in the process, either in the form of associations representing relevant interests (associational multi-stakeholderism) or through the direct participation of interested and affected individuals;

$>$ Participants have a real decision-making power and are not merely consulted;

$>$ Collaboration has a formal framework, distinguishing it from informal networks and interests groups;

$>$ The process is oriented to reach the consensus of participants (although full consensus is difficult to achieve) as opposed to authoritative decision-making;

$>$ The goal is the formation of public policies or the management of public resources.

In collaborative governance, the process of governing is thus articulated in a network of actors who are partners in decision-making: the state can be best conceived as a platform (O'Reilly, 2010) providing resources, rules and skills in order to build a "facilitating framework" for all the other stakeholders to collaborate (Dunleavy et al., 2005). In addition to citizens and the government, another actor gains importance in contemporary collaborative governance: online participatory platforms can in fact serve as tools helping both citizens and institutions sustain a continuous dialogue, share knowledge and competences, and foster collaborative processes (De Blasio, 2014).

Table 1. Actors and models of governance

\begin{tabular}{|c|c|c|c|}
\hline & Bureaucratic State & New Public Management & $\begin{array}{l}\text { Open Government (or } \\
\text { Collaborative Governance) }\end{array}$ \\
\hline Government & $\begin{array}{l}\text { Structure: unitary, } \\
\text { hierarchical and } \\
\text { professional } \\
\text { Agency: dominance } \\
\text { of rule of law }\end{array}$ & $\begin{array}{l}\text { Structure: flexible and } \\
\text { fragmented (autonomous } \\
\text { units) } \\
\text { Agency: managerial and } \\
\text { private-sector models }\end{array}$ & $\begin{array}{l}\text { Structure: network } \\
\text { Agency: government as } \\
\text { platform and facilitating } \\
\text { framework }\end{array}$ \\
\hline Citizens & External counterparts & Customers and clients & Partners \\
\hline Digital technology & n.a. & $\begin{array}{l}\text { e-government, e-service } \\
\text { delivery }\end{array}$ & $\begin{array}{l}\text { Participatory platforms to } \\
\text { dialogue and collaborate }\end{array}$ \\
\hline
\end{tabular}

Source: Original elaboration

We think that open government should be considered as a policy agenda that looks towards models of deliberative democracy and collaborative governance for the best possible means of implementation, while remaining a policy that can also be adapted to other models of administration. As a governance model, it enhances transparency 
through horizontal accountability mechanisms (Mulgan, 2014), such as the disclosure of public data (and recently, open data), the provision of tools to discuss and debate with administrators, while extending monitoring and enforcing powers of citizens. Participation can be achieved at increasing degrees: public consultations are just the first step for a fully shared decision-making. Deliberative arenas such as citizens' assemblies, citizens juries and public debates stand in an intermediate realm, because they open to a higher degree of participation than mere consultation, but still do not ensure that they are going to influence policy. Finally, collaboration can be actualized in three dimensions (De Blasio, 2014; Sorice, 2014): horizontal procedures involving multiple stakeholders; transversal policies shared by multi-level institutions such as supra-national, national, regional and local governments; and circular subsidiarity, notably in the form of public-privatecivic partnerships and "collaborative administration." Hence, open government can be conceived as a progressive stage model, from the access to information (in transparency) to full collaborative governance, in which the power of decision-making is symmetrical among all the participants (Table 2).

Table 2. Variables and dimensions of open government

\begin{tabular}{lll} 
Variables & Dimensions & Examples \\
\hline Transparency & Information and open data & Open data portals \\
& Training programs & Digital inclusion policies \\
& Public policies monitoring & Follow-the-money, access to information \\
\multirow{2}{*}{ Participation } & Consultation & On line consultation \\
& Deliberative arenas & Public debates, on line forums \\
& Co-decision of public policies & Co-drafting, consensus-oriented procedures \\
Collaboration & Horizontality & Multi-stakeholderism \\
& Transversality & Multi-level governance \\
& Collaborative governance & Public-private-civic partnership, \\
& & Shared decision-making \\
\hline
\end{tabular}

Source: Démocratie Ouverte, www.democratieouverte.org; De Blasio, 2014.

As a policy agenda, open government is composed of three variables or issues (transparency, participation and collaboration) and pays strong attention to the role of digital technologies in democratic processes. Although with relevant differences, this agenda indeed finds some common roots in the NPM ideal type ${ }^{6}$ (Table 3): in particular, NPM's approach to transparency emphasizes the accountability for results and the measurement of performance (Hood, 1991; Mulgan, 2014), while collaboration is exemplified in public-private partnerships and the "openness" to privatize administrative activities and to import market-style mechanisms (Hood, 1991; Osborne, 2010; Roberts, 2014), and the use of digital technology is mostly confined in a managerial logic of service provision (Reddick, 2011). Public participation in a deliberative perspective is somewhat neglected from the NPM agenda: basic feedback channels and direct democracy tools are only accepted as long as they provide insight into customer satisfaction (Hood, 1991).

\footnotetext{
${ }^{6}$ Although we acknowledge that NPM is a highly fragmented "cluster of phenomena" (Osborne, 2010) rather than a coherent doctrine, we treat it as an ideal type (using the Weberian concept of ideal type).
} 
Table 3. Comparison between NPM and open government.

\begin{tabular}{|c|c|c|}
\hline New Public Management & Variables & $\begin{array}{l}\text { Open Government } \\
\text { (or Collaborative Governance) }\end{array}$ \\
\hline $\begin{array}{l}\text { Accountability for results, } \\
\text { Measurement of performance } \\
\text { (Hood, 1991; Osborne, 2010; } \\
\text { Mulgan, 2014) }\end{array}$ & Transparency & $\begin{array}{l}\text { Horizontal accountability } \\
\text { Disclosure (open data), } \\
\text { Debate (civic skills), } \\
\text { Enforcement (monitoring) }\end{array}$ \\
\hline $\begin{array}{l}\text { Citizens as customers and clients; } \\
\text { Feedback as measurement of } \\
\text { performance; } \\
\text { Direct democracy to } \\
\text { counterbalance elitist character } \\
\text { (Hood, 1991) }\end{array}$ & Participation & $\begin{array}{l}\text { Consultation (conservative), } \\
\text { Deliberation (innovative), } \\
\text { Co-Decision (citizens as equal } \\
\text { partners) }\end{array}$ \\
\hline $\begin{array}{l}\text { Market-style mechanisms } \\
\text { (Hood, 1991; Osborne, 2010); } \\
\text { Public-private partnership } \\
\text { (Roberts, 2014) }\end{array}$ & Collaboration & $\begin{array}{l}\text { Networked governance } \\
\text { (Osborne, 2010); } \\
\text { Collaborative governance (Ansell } \\
\text { and Gash, 2007; Bingham, 2010); } \\
\text { Public-private-civic partnership, } \\
\text { circular; } \\
\text { State-platform approach } \\
\text { (O'Reilly, 2010) }\end{array}$ \\
\hline $\begin{array}{l}\text { Managerial model of } \\
\text { e-government (Reddick, 2011); } \\
\text { e-service delivery }\end{array}$ & Digital technology & $\begin{array}{l}\text { Consultative and participatory } \\
\text { models of e-government } \\
\text { (Reddick, 2011); } \\
\text { Digital democracy }\end{array}$ \\
\hline
\end{tabular}

Although all four variables of the open government agenda are interpreted in different ways, participation, collaboration and digital technology are the most challenging areas, because they imply a strong reform of public administration, whereas transparency goals (the disclosure of open data, the tools to debate and to monitor) can be easily achieved even without a major restructuring of government activity. Moreover, transparency is the only variable indicated in the earliest accounts of open government, dating from the 1950s, whereas participation, collaboration and digital technologies entered policy documents only in recent years (Clarke and Francoli, 2014). For those reasons, we would expect to find in different national policies more variance in the areas of participation, collaboration and digital democracy than in transparency.

\section{METHODOLOGICAL FRAMEWORK}

Our basic research question seeks to understand how open government is framed and used in the four countries we have been studying. It is also important to understand what variables are implied in the design of the participatory platforms in each country. In order to answer to our research questions, we adopt a comparative perspective focusing on four crucial cases in European countries, following the most similar/most dissimilar logic (Morlino, 2005; Engeli et al., 2014): the cases - as said - are France, Italy, Spain, and the 
UK. The dataset consists of a collection of three policy documents per country, selected on the grounds that each document represents a most common denominator, as they are derived from international, multilateral commitments: ${ }^{7}$ the national Digital Agenda Plans and the reuse of public sector information regulation derive from European Union commitments (absorbing respectively the European Digital Agenda and the directive 2013/37/EU on reuse of Public Sector Information) ${ }^{8}$, and the third document is the latest active Open Government Partnership Action Plan at the time of writing (July 2015).

Since our interest is in describing and analysing the different meaning and policy framing of open government among the selected countries, we have chosen an interpretive approach which considers policies as texts and communities of practices (Yanow, 2014): in particular, we focus on how policy-makers represent the problems they are facing, their way of solving them and the stakeholders they involve. This approach is relatively new in policy studies, but we were able to find some notable examples in the field of gender policies (Verloo, 2007) and climate change (Fletcher, 2009) in these fields the frame analysis is used to discover the motivations underlying the measures taken in the policy documents.

We made a first round of manual coding, applying frame analysis to the Open Government Partnership Action Plan of the four countries in order to build the codebook following a grounded approach, and to identify the whole spectrum of issues covered in the policy documents: we subdivided among specific measures undertaken or announced for each of the variables of open government (digital technology, transparency, participation and collaboration) and motivations for the adoption of such measures. We finally analysed the documents with qualitative, computer-assisted manual coding using the software QDA Miner in order to calculate the occurrences and co-occurrences of measures and frames through proximity plots, and to compare the different countries and policy documents. All the documents were retrieved from official sources in their entirety and analysed in their own native languages. Then we analysed the participatory platforms established by national and local authorities in Italy, France, the UK and Spain. Table 4 shows the dimensions, the variables and the indicators used in the analysis of the participatory platforms.

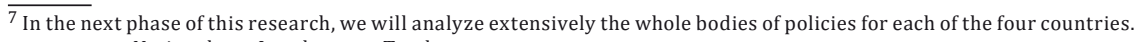
Nationals Locals Total

Italy $24 \quad 27 \quad 51$

France $\quad 17 \quad 22 \quad 39$

$\begin{array}{llll}\text { Spain } & 34 & 30 & 64\end{array}$

$\begin{array}{llll}\text { UK } & 34 & 16 & 50\end{array}$

Total $\quad 109 \quad 95 \quad 204$

The 204 policies will be analyzed in the frame of a "narrative policy framework", using an evaluation grid composed by eight steps (identification of the problem, collection of findings, construction of the alternatives, selections of criteria, outcomes detection, cost-benefits analysis, decision-making mechanisms analysis, redefinition of the process). This paper, anyway, presents only the first step of our research.

${ }^{8}$ United Kingdom had not implemented the directive yet at the time of writing: for this reason, we analyzed the most recent policy paper about open data, which was the 2014 Data Capability Strategy.
} 
Table 4. Dimensions, variables and indicators used in the analysis of the participatory platforms

\begin{tabular}{|c|c|c|}
\hline Dimensions & Variables & Indicators \\
\hline \multicolumn{3}{|l|}{ Design } \\
\hline & \multirow[t]{3}{*}{ Properties } & Code \\
\hline & & Fund raising \\
\hline & & Crowdfunding \\
\hline & \multirow[t]{5}{*}{ Accessibility } & Entrance \\
\hline & & Authentication \\
\hline & & Social authentication \\
\hline & & Anonymity \\
\hline & & Inclusiveness (selection criteria) \\
\hline & \multirow[t]{3}{*}{ Regulation } & Content policies \\
\hline & & Moderation \\
\hline & & Moderator role \\
\hline & \multirow[t]{2}{*}{ Discussion } & Agenda \\
\hline & & Articulation \\
\hline \multicolumn{3}{|l|}{ Information } \\
\hline & \multirow[t]{2}{*}{ Access } & Organised information \\
\hline & & Private sources \\
\hline & Production & Participatory production of contents \\
\hline \multicolumn{3}{|l|}{ Transparency } \\
\hline & Open data & Open Datasets \\
\hline & \multirow[t]{3}{*}{ Public policies monitoring } & Open data reuse \\
\hline & & Information on policies goals \\
\hline & & Reports \\
\hline \multicolumn{3}{|l|}{ Participation } \\
\hline & \multirow[t]{2}{*}{ Interaction } & Contact channels \\
\hline & & Feedback channels (like, sharing buttons) \\
\hline & Informal debate & Community spaces \\
\hline & \multirow[t]{3}{*}{ Formal consultation } & Aggregation of the preferences \\
\hline & & Free comments \\
\hline & & Formal proposals \\
\hline & \multirow[t]{7}{*}{ Open community } & Deliberative processes \\
\hline & & Multiple interactions \\
\hline & & Argumentation \\
\hline & & Respect and equality \\
\hline & & Orientation of the decision \\
\hline & & Experts \\
\hline & & Private actors (presence or not) \\
\hline & Democratic communities & Endogenous or bottom-up processes \\
\hline
\end{tabular}




$\begin{array}{lll}\text { Collaboration } & \begin{array}{l}\text { Horizontality - symmetry } \\ \text { of decision-making powers }\end{array} & \begin{array}{l}\text { Process reciprocity } \\ \text { Continuity } \\ \text { Output legitimacy } \\ \text { Accountability }\end{array} \\ \text { Transversality } & \begin{array}{l}\text { Policies interoperability } \\ \text { Collaborative governance }\end{array} & \begin{array}{l}\text { Actors and events interoperability } \\ \text { Presence of at least three social components } \\ \text { (ie public, private and civic) }\end{array} \\ & \begin{array}{l}\text { Action topic } \\ \text { Network communication and coordination }\end{array} \\ & \begin{array}{l}\text { Presence of a legal/institutional device as } \\ \text { background of collaboration (issued by the } \\ \text { same body that publishes the platform) } \\ \text { Mutuality of the legal/institutional device } \\ \text { Binding nature of the process } \\ \text { (if a "device" is present) } \\ \text { Binding nature of the process } \\ \text { (if a "device" is NOT present) }\end{array} \\ \end{array}$

\section{FINDINGS}

Our analysis shows that the four European countries have similarities and differences in both the measures undertaken and the frames in which they deploy to motivate their actions (Graph 1).

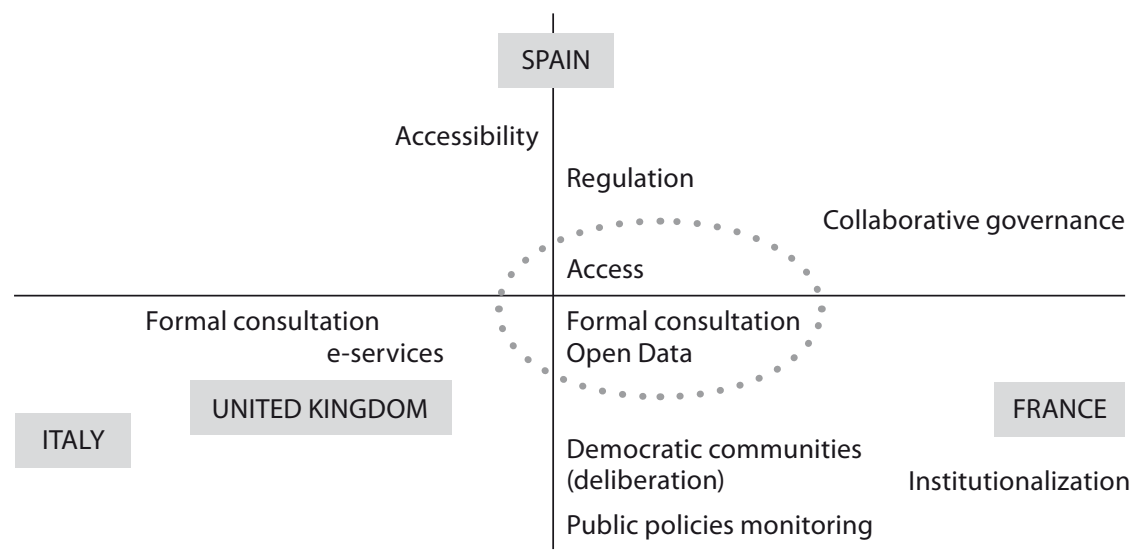


In particular, if we look at our measures, we find a least common denominator in issues about access, open data and financial accountability, confirming our assumption: all countries dedicate much more attention to transparency than to participation and collaboration. Another feature among all of the policies is the common reference to consultation practices. All countries are increasingly consulting the public and the private sector during the policy-making process, but again this convergence can be explained by looking at the requirements in the Open Government Partnership: all Action Plans must be elaborated in consultation with civil society organizations. Aside from that event, we found that most consultations do not imply a co-decision procedure nor a deliberative process, but are instead intended to come from the recommendations of private actors and civil society organizations, or via public survey. Deliberative processes are best implemented in French policies (both at the legislative and at implementation levels), notably in matters of environment protection and territory management. The government is currently adopting measures to make deliberation a transversal procedure. ${ }^{9}$

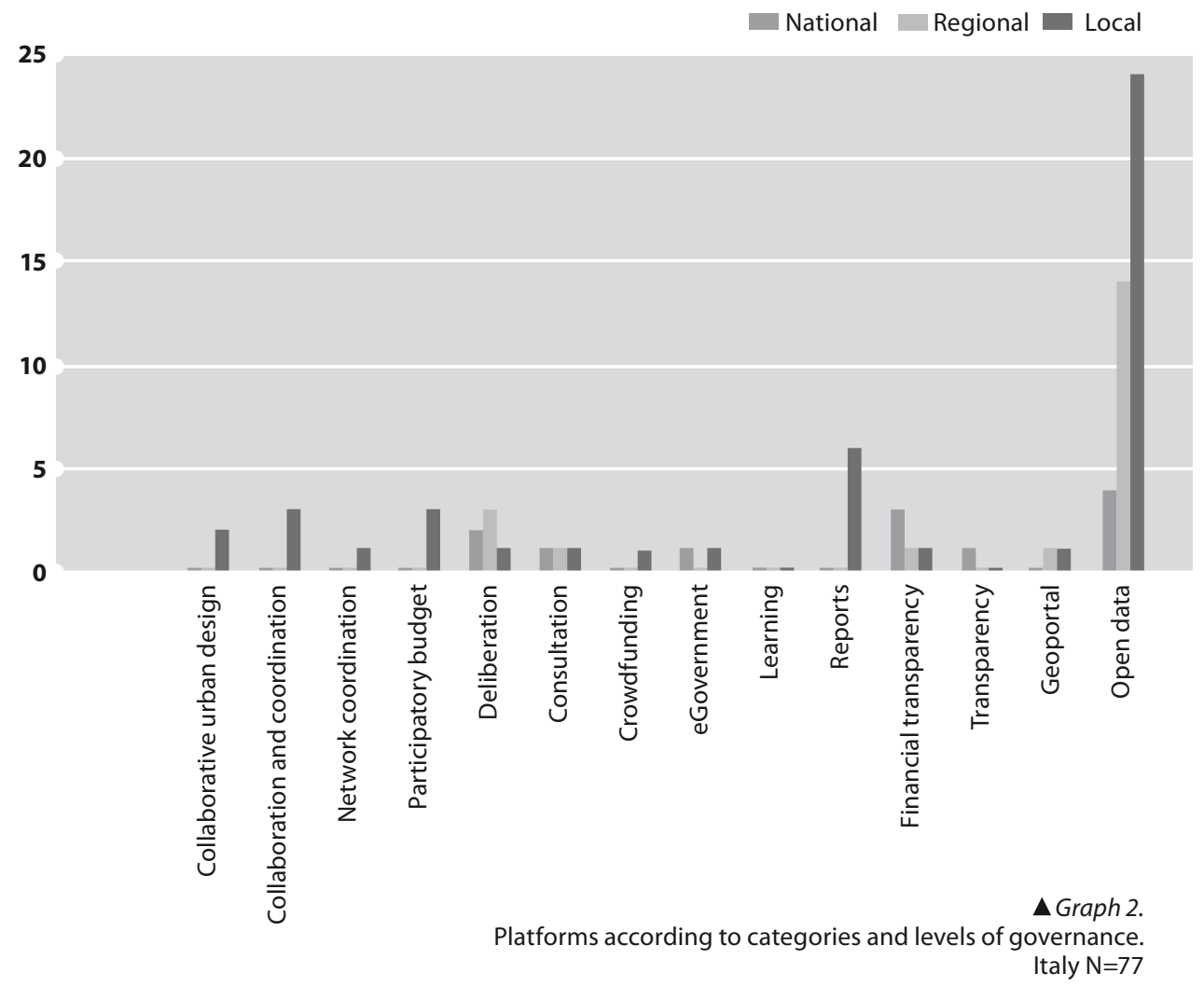

\footnotetext{
${ }^{9}$ In 1995 the French "Law Barnier" on environment protection introduced the public debate as a common practice for deliberative decision-making in specific sectors (notably infrastructure, territory management and energy) and instituted a specialized Commission (later enhanced to the status of authority). Currently the Commission is working to coordinate the deliberative design with digital procedures and to extend the matters of deliberation.
} 
The policies' implementation (say, the digital participatory platforms) shows evidence of some differences when compared to the official documents.

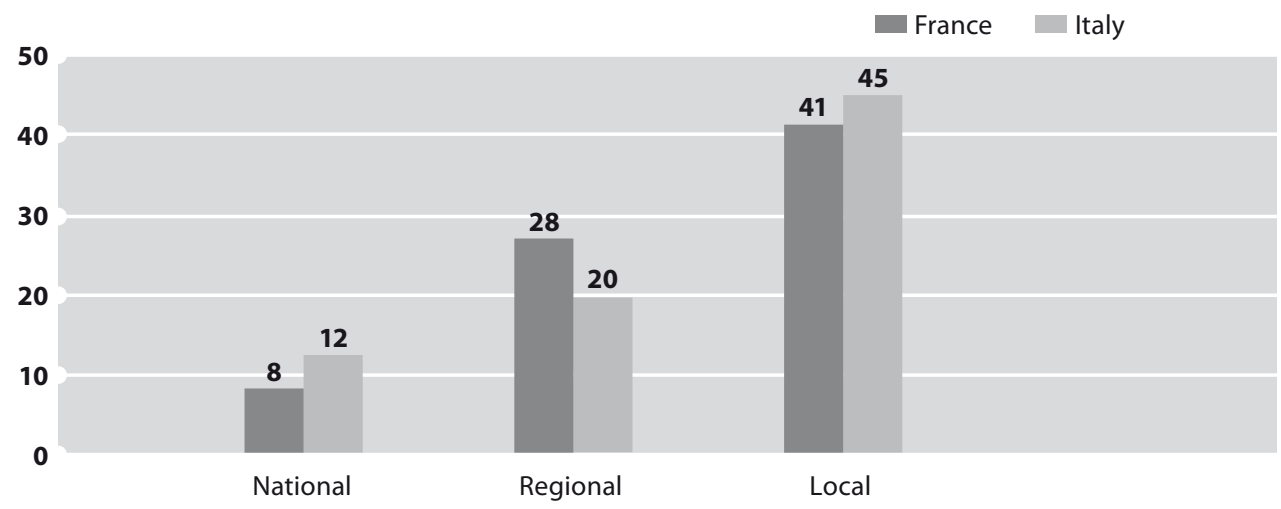

A Graph 3.

Platforms for different levels. France and Italy

In Graph 2, the different categories of platforms are also considered from a geographical point of view. The difference among levels (national, regional and local) is better highlighted in the Graph 3.

Graph 3 shows the differences between France and Italy at the different-institutional level. Graph 4 describes the mere differences between open data platforms and participatory ones among France, Italy and the UK; at this step, it seems that the UK presents a higher percentage of participatory platforms (it is important to remember, however, that the definition of "participatory platforms" is wide and it deserves a more analytical, theoretical effort of understanding).

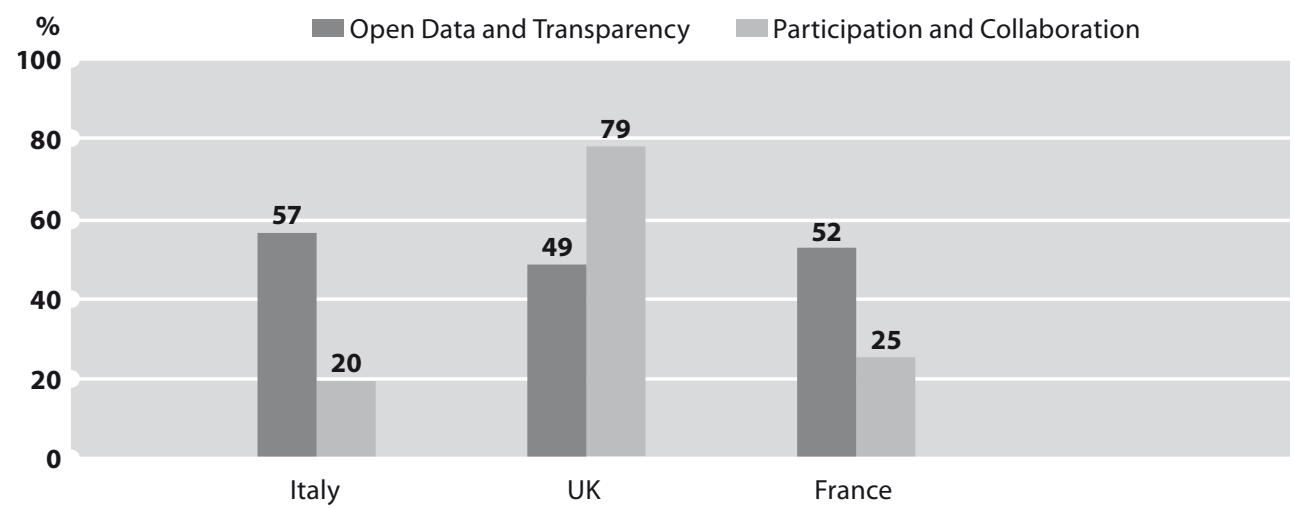


Platforms for open data (and transparency) are the most common, both in France and in Italy. If we consider geoportals (very often associated to tourism and leisure even from a "transparency perspective") and transparency platforms as both framed in a specific macro-category (open data and transparency), we can easily see that they represent around the $60 \%$ of all the platforms in Italy and France. It means that only $40 \%$ of the platforms are specifically designed to improve participation and collaboration between citizens and institutions. This situation is evident if we compare data from France and Italy with those of the United Kingdom (Graph 4). In this case (and in considering open data and transparency we also include financial transparency, claims/consultations and network coordination) we can easily note as the platforms specifically designed for participation are in greater number in UK than in France and Southern Europe. It does not mean that participation is more efficient in the UK, but only that the national infrastructure for digital participation is more developed. At the same time, however the French websites for open data and transparency also call for participation (in the tradition of the débat public), while in Italy they have a prominent top-down communication model.

\section{DISCUSSION AND CONCLUSIONS}

Our study helps to clarify the meaning of open government by looking at policy implementation and at the policy content as it relates to transparency, participation, collaboration and digital technologies, all which constitute what we called the open government agenda. By studying policy documents from France, Italy, Spain and the United Kingdom we found that transparency and digital technologies are the most prominent issues, whereas participation and collaboration are less considered and implemented.

This homogeneity can depend on a series of concurrent factors: first the time factor, in the sense that transparency can count on a longer tradition of implementation, notably the access to information. A legal factor is the common background of those countries, all of which are members of the European Union. The trend towards policy convergence is sustained by the regulatory activity of European institutions, which is still more focused on transparency than participation. A technological factor resides in the opportunities of digital technologies that contribute to enhancing the accessibility of information, thereby enlarging the quantity of information and widening the audience. And a final economic factor is evident in the frame used by all countries: data are considered resources for economic growth and the development of new businesses.

The study on policy frames highlights some differences among countries in the motivation for the adoption of open government policies. In particular, the scarce attention paid to participation and collaboration compared to transparency is reflected in the modest activation of what we called the democratic frame, containing references to democratic values such as participation, transparency, equality, inclusion, trust, and privacy rights. 
Analysing the digital platforms (77 in Italy, 77 in France, 76 in Spain, 130 in the UK) we have to highlight some peculiar differences. First of all the higher number of platforms in the UK; then the peculiarities of the UK with respect to the other three countries. If France shows some specific issues in the policy documents, it is the UK that has a clear specificity in the platforms (or, in the policies implementation). The UK, in other words, appears to have issues not unassimilable to the other three countries.

At the moment, the model of collaborative governance is hardly being implemented into national policies and the open government agenda remains at the level of transparency measures (with some exceptions). Notwithstanding, we could detect different perspectives and motivations for the adoption of open government measures that constitute the proof of a vital debate currently ongoing: in particular, we expect to see different, main models of open government being discussed, adapted and changed in the next few years.

\section{References}

$>$ Ansell, Chris and Gash, Alison (2007) Collaborative Governance in Theory and Practice. Journal of Public Administration Research and Theory 18 (4): 543-571. DOI: 10.1093/jopart/mum032.

$>$ Asp, Kent (1986) Mäktiga Massmedier [Powerful Mass Media]. Stockholm: Akademilitteratur. >Blomgren Bingham, Lisa (2010) The Next Generation of Administrative Law: Building the Legal Infrastructure for Collaborative Governance. Wisconsin Law Review 2010 (2): 297-356.

>Castells, Manuel (1996) The Rise of the Network Society: The Information Age: Economy, Society, and Culture Volume I. Oxford: Blackwell. DOI: 10.1002/9781444319514 (edition 2009).

>Clarke, Amanda and Francoli, Mary (2014) What's in a Name? A Comparison of 'Open Government' Definitions across Seven Open Government Partnership Members. eJournal of eDemocracy and Open Government 6 (1): 248-266.

>Crouch, Colin (2011) The Strange Non-Death of Neoliberalism. Cambridge: Polity.

$>$ Crouch, Colin (2003) Postdemocrazia [Post-democracy]. Roma-Bari: Laterza.

>Dalton, Russell J. (2000) Value Change and Democracy, pp. 252-269 in Pharr, S. J. and Putnam, R. (eds) Disaffected Democracies: What's Troubling the Trilateral Countries?. Princeton: Princeton University Press.

>De Blasio, Emiliana (2014) Democrazia digitale. [Digital Democracy] Roma: LUISS University Press. $>$ De Blasio, Emiliana and Sorice, Michele (2014) Radicals, Rebels and Maybe Beyond. Social Movements, Women's Leadership and the Web 2.0 in the Italian Political Sphere. Roma: CMDI LUISS. >della Porta, Donatella (2013) Can Democracy Be Saved? Participation, Deliberation, and Social Movements. Cambridge: Polity Press.

>Denhardt, Robert B. and Vinzant Denhardt, Janet (2000) The New Public Service: Serving rather than Steering. Public Administration Review 60 (6): 549-559. DOI: 10.1111/0033-3352.00117.

>Diamond, Larry and Morlino, Leonardo (2005) Assessing the Quality of Democracy. Baltimore: The John Hopkins University.

>Dunleavy, Patrick, Margetts, Helen, Bastow, Simon and Tinkler, Jane (2005) New public management is dead - long live digital-era governance. Journal of Public Administration Research and Theory 16 (3): 467-494. DOI: 10.1093/jopart/mui057.

$>$ Easton, David (1965) A Framework for Political Analysis. Englewood Cliffs, NJ: Prentice-Hall. $>$ Engeli, Isabelle and Rothmayr Allison, Christine (eds) (2014) Comparative Policy Studies: Conceptual and Methodological Challenges. Basingstoke: Palgrave MacMillan. DOI: 10.1057/9781137314154. >Fabbrini, Sergio (1999) II principe democratico. La leadership nelle democrazie contemporanee. [The Democratic Prince. Leadership in Contemporary Democracies] Roma-Bari: Laterza. 
>Fishkin, James S. (1991) Democracy and Deliberation. New Directions for Democratic Reform. London: Yale University Press.

>Fletcher, Amy Lynn (2009) Clearing the Air: the Contribution of Frame Analysis to Understanding Climate Policy in the United States. Environmental Politics 18 (5): 800-816. DOI: 10.1080/09644010903157123.

$>$ Fung, Archon and Wright Erik Olin (2001) Deepening Democracy: Innovations in Empowered Participatory Governance. Politics \& Society 29 (1): 5-41. DOI: 10.1177/0032329201029001002. $>$ Hood, Christopher (1991) A Public Management for All Seasons?. Public Administration 69 (1): 3-19. $>$ Hood, Christopher and Peters, Guy (2004) The Middle Aging of New Public Management: into the Age of Paradox?. Journal of public administration research and theory 14 (3): 267-282. DOI: 10.1093/ jopart/muh019.

>Kaase, Max and Newton, Kenneth (1995) Beliefs in Government. New York: Oxford University Press. DOI: 10.1093/0198294727.001.0001 (edition 1998).

$>$ Katz, Richard S. (ed.) (1987) Party Governments: European and American Experiences. BerlinNewYork: W. de Gruyter, European University Institute.

>Lipset, Seymour Martin and Rokkan, Stein (1967) Party Systems and Voter Alignments: Cross-national Perspectives. New York: The Free Press.

$>$ Mair, Peter (2000) Partyless Democracy. Solvingthe Paradox of New Labour?. New Left Review 2 (2): 21-35.

$>$ Manin, Bernard (1995) Principes du gouvernement représentatif [Principles of Representative Government]. Paris: Calmann-Lévy.

>Margetts, Helen and Dunleavy, Peter (2013) The Second Wave of Digital-era Governance: a QuasiParadigm for Government on the Web. Philosophical Transactions of The Royal Society A 371 (1987): 141-166. DOI: 10.1098/rsta.2012.0382.

>Morlino, Leonardo (2011) Changes for Democracy. Actors, Structures, Processes. Oxford: Oxford University Press.

>Morlino, Leonardo (2005) Introduzione alla ricerca comparata [Introduction to Comparative Research]. Bologna: II Mulino.

$>$ Morlino, Leonardo, Piana, Daniela and Raniolo, Francesco (eds) (2013) La qualità della democrazia in Italia (The Quality of Democracy in Italy). Bologna: II Mulino.

>Mulgan, Richard (2014) Making Open Government Work. Basingstoke, UK: Palgrave MacMillan. $>$ Noveck, Beth S. (2010) The Single Point of Failure, pp. 49-69 in Lathrop, Daniel and Ruma, Laurel (eds) Open Government: Collaboration, Transparency, and Participation in Practice. Sebastopol, CA: O'Reilly Media.

>O'Flynn, Ian (2006) Deliberative Democracy and Divided Societies. Edinburgh: Edinburgh University Press.

$>0$ 'Reilly, Tim (2010) Government as a Platform, pp. 11-40 in Lathrop, Daniel and Ruma, Laurel (eds) Open Government: Collaboration, Transparency, and Participation in Practice. Sebastopol,

CA: O'Reilly Media.

>Osborne, Stephen P. (ed.) (2010) The New Public Governance? Emerging Perspectives on the Theory and Practice of Public Governance. London: Routledge.

>Pharr, Susan J. and Putnam, Robert (eds) (2000) Disaffected Democracies: What's Troubling the Trilateral Countries?. Princeton: Princeton UniversityPress.

>Pollitt, Cristopher and Bouckaert, Geert (2004) Public Management Reform: A Comparative Analysis. Oxford: Oxford University Press.

$>$ Rahat, Gideon and Sheafer, Tamir (2007). The Personalization(s) of Politics: Israel 1949-2003.

Political Communication 24 (1): 65-80. DOI: 10.1080/10584600601128739.

$>$ Reddick, Christopher G. (2011) Citizen Interaction and E-government: Evidence for the Managerial, Consultative, and Participatory Models. Transforming Government: People, Process and Policy 5 (2): 167-184. DOI: 10.1108/17506161111131195.

>Roberts, John Michael (2014) New Media and Public Activism. Neoliberalism, the State and Radical Protest in the Public Sphere. Bristol: Policy Press. 
IZVORNI ZNANSTVENI RAD / DOI: 10.20901/ms.7.14.3 / PRIMLJENO: 18.03.2016.

>Sartori, Giovani (1987) Theory of Democracy Revisited, Chatam House Publishers, New York. >Shapiro, Ian (2003) The State of Democratic Theory. Princeton: Princeton University Press. DOI: 10.1515/9781400825899 (edition 2009).

$>$ Sorice, Michele (2014) I media e la democrazia [The Media and Democracy]. Roma: Carocci. >Streeck, Wolfgang (2014) Buying Time: The Delayed Crisis of Democratic Capitalism. London and New York: Verso Books.

$>$ Verloo, Mieke (ed.) (2007) Multiple Meaning of Gender Equality: A Critical Frame Analysis of Gender Policies in Europe. Budapest: Central European University Press.

$>$ Weber, Max (2002) Parlamento e governo. Per la critica politica della burocrazia e del sistema dei partiti [Parliament and Government: Political Critics of Bureaucracy and of Parties' System]. Bari: Laterza.

>Yanow, Dvora (2014) Interpretive Analysis and Comparative Research, pp. 131-159 in Engeli, Rothmayr Allison (eds) Comparative Policy Studies: Conceptual and Methodological Challenges. Basingstoke: Palgrave MacMillan. DOI: 10.1057/9781137314154. 


\section{OTVORENA VLADA KAO ALAT DEMOKRACIJE}

\section{Emiliana De Blasio :: Michele Sorice}

SAŽETAK Sve veća nepovezanost građana i donositelja odluka gura politiku u smjeru koji će dovesti do preoblikovanja institucionalnog aranžmana. Komunikacijski alati mogu imati važnu ulogu u razvijanju novih prostora za participaciju građana. Postoje različiti modeli kojima vlada ijavna administracija mogu poduprijeti građansku participaciju: e-vlada, otvorena vlada i specifičan dizajn digitalne demokracije. Otvorena vlada može biti jedan od načina za ponovno povezivanje građana i političkih institucija, ali u isto vrijeme može biti i „privlačan“ alat za institucionalizaciju participacije odozdo prema gore i njezino umrtvljivanje. Cilj je ovog rada predstaviti prva saznanja međunarodnog istraživačkog projekta na temu otvorene vlade i participacijskih platformi u četiri europske države (Francuskoj, Italiji, Španjolskoj i Ujedinjenom Kraljevstvu). Istraživanje nastoji otkriti mogu li platforme za participaciju poboljšati kvalitetu demokracije i može li otvorena vlada doprinijeti demokratizaciji demokracije.

KLJUČNE RIJEČI

OTVORENA VLADA, PARTICIPACIJA, KOMUNIKACIJA, DEMOKRACIJA, DEMOKRATSKE INOVACIJE

Bilješka o autorima

Emiliana De Blasio :: LUISS University, Department of Political Sciences, Rim, Italija i SciencesPo, Pariz, Francuska :: edeblasio@luiss.it

Michele Sorice :: LUISS University, Department of Political Sciences, Rim, Italija i University of Stirling, Communication Media and Culture, Škotska, Ujedinjeno Kraljevstvo ::

michele.sorice@stir.ac.uk 